\title{
Conceptual bases in restoration of scientific vertebrate collections
}

\author{
Mugnai, R. $^{a *}$, Oliveira, $J A .^{b}$ and Oliveira, $L F B .^{b}$ \\ ${ }^{a}$ Setor Aracnologia, Departamento de Invertebrados, Museu Nacional, Universidade Federal do Rio de Janeiro - UFRJ, \\ Quinta da Boa Vista, s/n, São Cristóvão, CEP 20940-040, Rio de Janeiro, RJ, Brazil

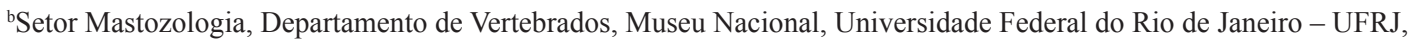 \\ Quinta da Boa Vista, s/n, São Cristóvão, CEP 20940-040, Rio de Janeiro, RJ, Brazil \\ *e-mail: mugnai.riccardo@gmail.com
}

Received: March 19, 2013 - Accepted: August 8, 2013

(With 5 figures)

\begin{abstract}
The scientific heritage preserved in Brazilian biological collections has inestimable value. Despite the research on curation and restoration of biological material is regarded as strategic, there is a lack of expertise in these areas in the country. These deficiencies often determine the use of obsolete or even inadequate procedures aimed at the recovery of material for research or exhibition, resulting in risk to valuable specimens. In the present work we provide a review of the literature on the restoration of biological specimens and summarize concepts employed in the restoration of mammals and birds of the Museu Nacional, Universidade Federal do Rio de Janeiro, exhibition in 2011. The aim of this work is to contribute to the development of protocols when interventions are needed to restore damaged specimens.
\end{abstract}

Keywords: scientific collections, curatory, restoration, concepts, methods.

\section{Bases conceptuais para o restauro de coleção científicas de vertebrados}

\section{Resumo}

O patrimônio científico e cultural conservado em coleções biológicas no Brasil é de reconhecida importância. Entretanto, há carência de pesquisas sobre estratégias de restauro e gerenciamento de material biológico em coleções, como também de especialistas nestas áreas, apesar de serem consideradas estratégicas. Essas lacunas podem acarretar na utilização de protocolos obsoletos ou mesmo inadequados de trabalho, pondo em risco espécimes valiosos de um acervo científico. Neste trabalho, apresentamos uma revisão da literatura sobre restauração de espécimes biológicos, e resumimos os princípios que nortearam as atividades de restauração dos espécimes de mamíferos e aves taxidermizados da exibição do Museu Nacional em 2011, no sentido de contribuir para a elaboração de protocolos quando intervenções são necessárias para restaurar espécimes danificados.

Palavras-chave: coleções científicas, conceitos, curadoria, métodos, restauro.

\section{Introduction}

Biological collections have formed the material basis of knowledge on biodiversity, allowing to catalog species and to carry out studies and analyses (Lange Canhos et al., 2004). In a period of growing demand for knowledge on biodiversity by the scientific community and by the Society, biological collections constitute active centers for education, conservation and biodiversity research (Krishtalka and Humphrey, 2000; França and Callisto, 2007).

The Museu Nacional is the oldest scientific institution and the oldest museum in Brazil, having been created in 1818 , by a decree by King D. João VI, who remodeled a previous trading office known as "Casa dos Pássaros" (House of Birds) created few decades before by Queen Maria I. Currently, the museum hosts nine million biological specimens. The vertebrate collections account approximately for 750,000 specimens, a small part of which is prepared for display in a 4,000 m2 area (Safra, 2007). In 2006 the exhibition halls reserved to Zoology were closed to visitation to allow renovation of the old building structure. Many of the specimens in the exhibition halls were in need of interventions to ensure conservation and to improve their aesthetic condition. These specimens had damages such as cracking due to dehydration, variation in temperature and humidity or shocks, dust and infestation by fungi, mites, and insects. Moreover, several specimens had problems due to previous restorations performed with inappropriate methodologies and/or materials.

Several interventions have been performed on these specimens in order to restore their damaged parts. Likewise, the display cases in which the specimens were exhibited were also restored and modified to improve long term preservation of specimens while exploring more attractive 
display resources, such as the use of artificial light sources, in acquaintance with the role of the museum exhibitions as a place of cultural mediation.

Biological collections in Brazilian institutions, most of them belonging to public universities or research institutes, are usually in charge of faculty members or researchers which are not necessarily experienced with curatorial procedures or restoration techniques, especially when it concerns to mounted specimens for exhibition. Likewise, there is a lack of research on the restoration of scientific and display collections of biological material in the country, despite the long considered strategic nature of such research (Cato et al., 2001). This situation eventually leads to the use of inadequate procedures for the longterm preservation of biological specimens in most of the collections. In order to contribute to the discussion on the preservation of biological specimens, and to document the procedures used for restoration and preservation of such material, we herein present a summary of the principles and strategies of the reorganization and restoration activities in the mammals and birds specimens stored in the vertebrates exposition section of the Museu Nacional, Universidade Federal do Rio de Janeiro, Brazil, during the year 2011.

\section{Basic Concepts}

The development and test of methodologies and materials for repair and restore of damaged specimens is one of the highest priorities to conserve natural history collections (Cato et al., 2001). Before the application of standardized curatorial procedures in collections and exhibition areas, it is necessary to evaluate the specificities of each collection (Mugnai and Agnelli, 2008; RGI, 2000; Williams and Walsh, 1989). Similar care should be taken before any intervention aiming the restoration of the specimen aesthetic condition (Borgo and Doria, 2008; Lotti and Barbagli, 2008). The procedure to be chosen should result from mediation of demands and needs of curator and technical specialist staff in conservation and restoration (Pilette and Harris, 1989). Finally, it is necessary that techniques planned or reported in the literature consider biohazard agents and chemical hazard in laboratories, collections and exhibition spaces (Brasil, 2006; Hawks et al., 2010; Lapa, 2006). To develop activities in an old collection, it is first necessary to set the differences and boundaries between curatory and restoring activities. Curatory is the set of actions routinely implemented in order to ensure the integrity of specimens in collections and the associated information (Herholdt, 1990; Horie, 1986). Cato and Williams (1993) and Simmons and Munhoz-Saba (2005) discuss conservation activities in biological collections and distinguish between preventive and restoration actions. According to these authors, preventive conservation activities involve physical and/ or chemical actions applied to specimens of the collection as a whole in order to minimize or eliminate chemical, physical or biological damage. These activities include, for example, the introduction of preservatives or spraying. In contrast, restoration include more or less punctual activities, focused on the aesthetic and physical recovery of damaged specimens or their cleaning (Brandi, 1977). Herholdt (1990) mentions the need to include technicians specifically trained to take care of the damaged specimens as part of the staff of a scientific institution.

The curatory activities are under responsibility of the curator or the manager curator depending on the institution (Herholdt, 1990; Simmons and Munhoz-Saba, 2005). For this activity an extensive bibliography is available, for example Rose and Torres (1992), Michalski (1994), National Park Service (2005), Simmons and Munhoz-Saba (2005), and Rose et al. (1995). Likewise, for the technical preparations and artistic taxidermy an extensive bibliography is available: Clevedon Brown and Stoddard (1977), Cousin and Dubosc (1991); Scrocchi and Kretzschmar (1996), Simmons and Munhoz-Saba (2005), Van Veen (1981).

In the virtual absence of a career in conservation of biological material, the restoration of exhibition vertebrate specimens has been traditionally delegated to taxidermists (Barbagli, 2008). Differently from curatorial activities and taxidermy, the restoration of biological specimens is poorly defined and its bibliography is scarce, with locally distributed or gray literature, mostly published as abstracts or papers in conferences and symposia and reports.

Often, taxidermy books (e.g., Ragionieri, 1961; Van Veen, 1981) address this matter only in a limited way, for example, when referring to the replacement of broken feathers of birds. In most cases, the restoration activity is intended only as a set of interventions with main purpose to recover the aesthetic of specimens. As consequence, sometimes, a new preparation of the specimen is carried out (Barbagli, 2008). Brandi (1977, p. 8) wrote: "[...] The restoration must address the potential reestablishment of the unity of artwork, whenever possible, without introducing historical or art forgery and not erasing the marks of the time course".

Therefore, the restoration of a specimen, as an artwork, must consider both aspects of scientific research and historic value of the material, without creating artifacts. Consequently, any action must be carefully planned, the whole process should be documented and the techniques and materials used should be reversible (Mugnai and Agnelli, 2008; Simmons and Munhoz-Saba, 2005).

The lack of a documented protocol for the implementation of restoration of biological specimens often is reflected in the terminology. For example, in the present study we have used the term "cleaning" instead "hygienization" as used in other restoration areas in Brazil (Guimarães and Beck, 2007; Güths and Rodrigues de Carvalho, 2007) and as suggested by our colleagues, since we judged the latter unsuitable, for example, in the case of partial removal of biological tissues in skeletons mounted with natural ligaments.

Below we relate some of the most discussed topics during the restoration activities in the Vertebrates collection of the Museu Nacional. 


\section{Specimen Associated Information}

Because a specimen is both a constituent of a scientific collection and a historical element, the first step in the restauration process is to track the information associated to the mounted specimen, either directly or indirectly. This information is often recorded in a label or labels fixed underside mounting bases, sometimes one over the other, which may indicate renewal of labels, as a result of taxonomic synonymy or deterioration of the old labels (Figure 1a). Alternatively, the information may be written directly into the bases, often in pencil (Figure 1b). The writing in graphite tends, unlike the ink, to reflect light when illuminated, which facilitates its detection in heavily dusted surfaces, simply by moving a light source above the surface.

Important data can be linked indirectly to the specimen. Mounting bases of particular materials, shapes, colors and styles, types of support, as well as methods used to twist irons and styles of suturing can serve to link a specimen to a collection, an exhibition or a technician (Figures 2a, b, c, d, 3a, b). Therefore, simple activities such as replacing or painting bases, replacing or shortening irons or even replacing sutures can result in modification of the original preparation and in the impossibility to the retrieve information by comparison with other specimens of the same series. Therefore, these activities should be evaluated case by case, and should always be documented.

\section{Genetic Data}

Specimens should be considered sources of future research. That implies knowledge of new and old research techniques. Over the past thirty years, there has been a change in the paradigm of systematic and taxonomic analyses, with an increasing importance of genetic methods. Dry and wet specimens in collections also contain biological tissues for potential extraction of genetic material. The technique of ancient DNA, allowing recovery of the genetic code even in a fragmentary or incomplete way, has opened new perspectives for research. With this methodology, specimens stored in natural history collections can be used as a source of genetic data in biodiversity research including extinct taxa (Hofreiter et al., 2001).

Genetic analysis may be affected by several factors. DNA naturally tends to degrade with time (Dauxois et al., 1993; Wartell and Benight, 1985), but the process is accelerated by ultraviolet radiation (Marmur et al., 1961), thermal stress and extreme conditions of $\mathrm{pH}$, both in acidic or alkaline conditions (Höss et al., 1996). Finally, it should be considered the problem of contamination by possible gene residues of other organisms, in particular from the technicians, especially in primate studies (Cooper and Poinar, 2000).

Genetic data can also be affected by products and techniques used in the process of restoration or cleaning. Some authors recommend several different cleaning products such as ammonia, bleach, trichlorethylene, acetone, ether, cyclohexane and gasoline. De Wet et al. (1990) and Jannett Junior and Davies (1989) reported examples of techniques for eliminating fat from the bones, Brunstetter (1988) for removing stains and rust, and Graham and Spafford (2001) for removing soot. For disinfection of large sized specimens Marchetti (1984, p.178-179) provides “[...] a system ... which does not involve the danger of carbon sulfide is the vapors of formalin and borax. In a pressure pot insert $1 \mathrm{~kg}$ of borax powder and 10 liters of formalin. Replace the valve pan with a plastic hose and insert side of the hose with a large syringe needle. When boiling, gently puncture the whole subject and make it also the inner parts are impregnated and steam [...] Continue until the steam injected into the subject's center of each side escapes [...]". Some of these techniques can be considered outdated, as they may cause loss of genetic material of the specimens. They are nevertheless useful, due to the difficulty of using large size fumigation chambers or to use freezing treatment as consequence of the dismantlement of the cold chambers to freeze specimens in many institutions. However, before choosing the techniques and chemicals to be used in cleaning activities, it is important to consider a whole range of factors including the possibility that

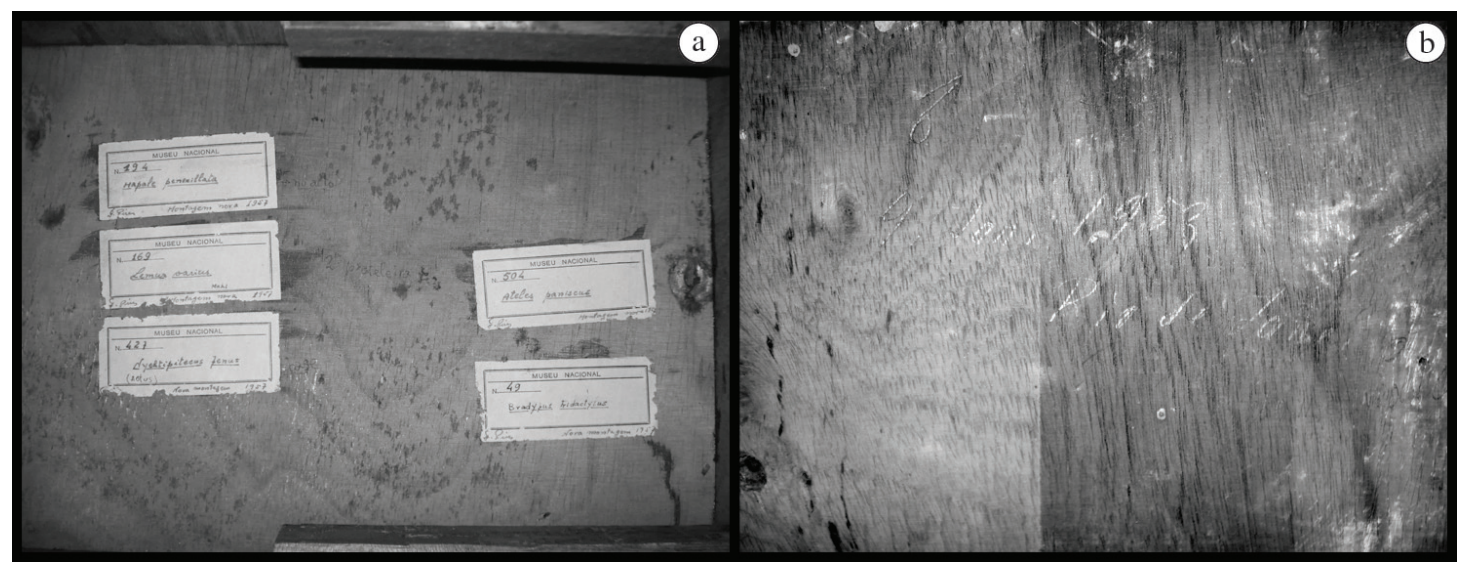

Figure 1. a - labels in the underside of a base; $b$ - graphite writing in the underside of a base. 


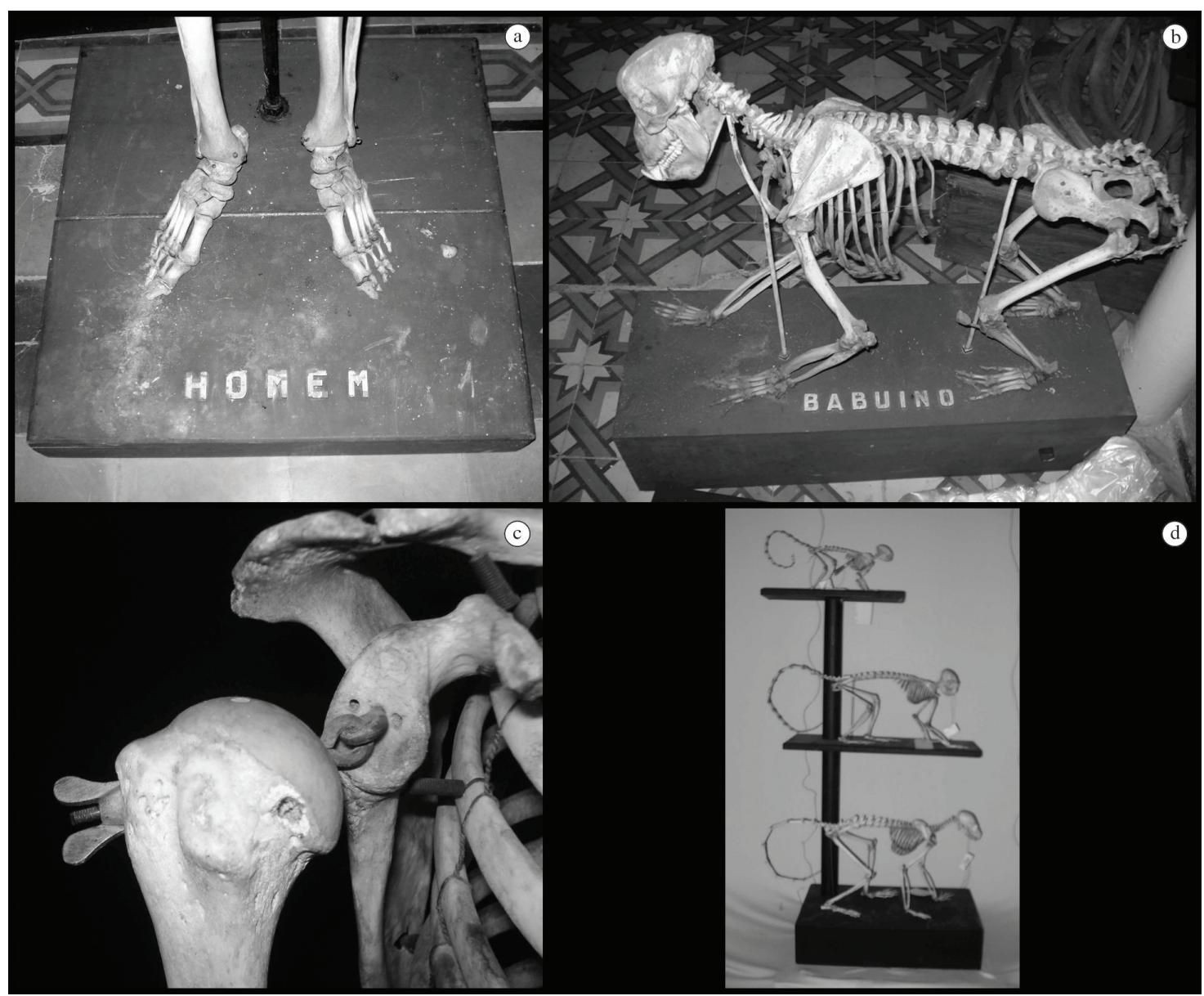

Figure 2. a - base of Homo sapiens n. 118 collection of the Department of Anthropology; b - base of Papio sp. without number; the dark blue color and writing in relief indicate that the both specimens were part of the exhibition at the National Museum in 1949; c - iron shoulder, Homo sapiens n. 118 removed during the restoration; d - Callithrix penicillata MN 194, Aotus sp. MN 427 and Varecia sp. MN 169, the multiple bases and the originally light blue color indicates that the specimens were used in the exhibition of 1957.

products can denature proteins or nucleic acids of the specimen decreasing the potential use in genetic studies.

To restore severely damaged specimen parts, such as hairless areas or broken beaks, a common procedure is to replace the damaged structure with that of a distinct specimen, as recommended by Marchetti (1984, vol. I, p.130-131). This technique, despite useful when applied for mounted specimens for exhibition can, nevertheless, create genetic artifacts when implemented without adequate documentation.

\section{Colors}

One of the most critical problems in exhibition specimens is the loss of the natural coat color. This loss may be due to environmental factors such as direct sunlight or ultraviolet light produced by lamps (Rose and Torres, 1992; Simmons and Munhoz-Saba, 2005) or due to chemical agents such as borax and alum used in specimen preparation (Coetzee, 1985; Florian, 1986).
Recovery of color using dyes is possible, but our experience showed that recovering the total coloring of a specimen is limited both in the reproduction of the natural color and of the color variation throughout the body. A relevant factor in this sense is the dilution of the dye used, considering its consistency and correlated risk of covering and masking characteristic details such as small hairs, wrinkles and local variation of skin color (Figures 4a, b, $5 \mathrm{a}, \mathrm{b})$. A related issue with color recovering consists of the tint superficial texture. Special effects created with oil paints, waxes and hair spray, are often short lived, and in time such products tend to favor the adhesion of dust; therefore, they should not be used.

\section{A Case Study: Results of Restoration Activities Developed in the Museu Nacional Exhibits}

In the year 2011, to organize the rooms of Brazilian mammals and birds, as well as the comparative anatomy 


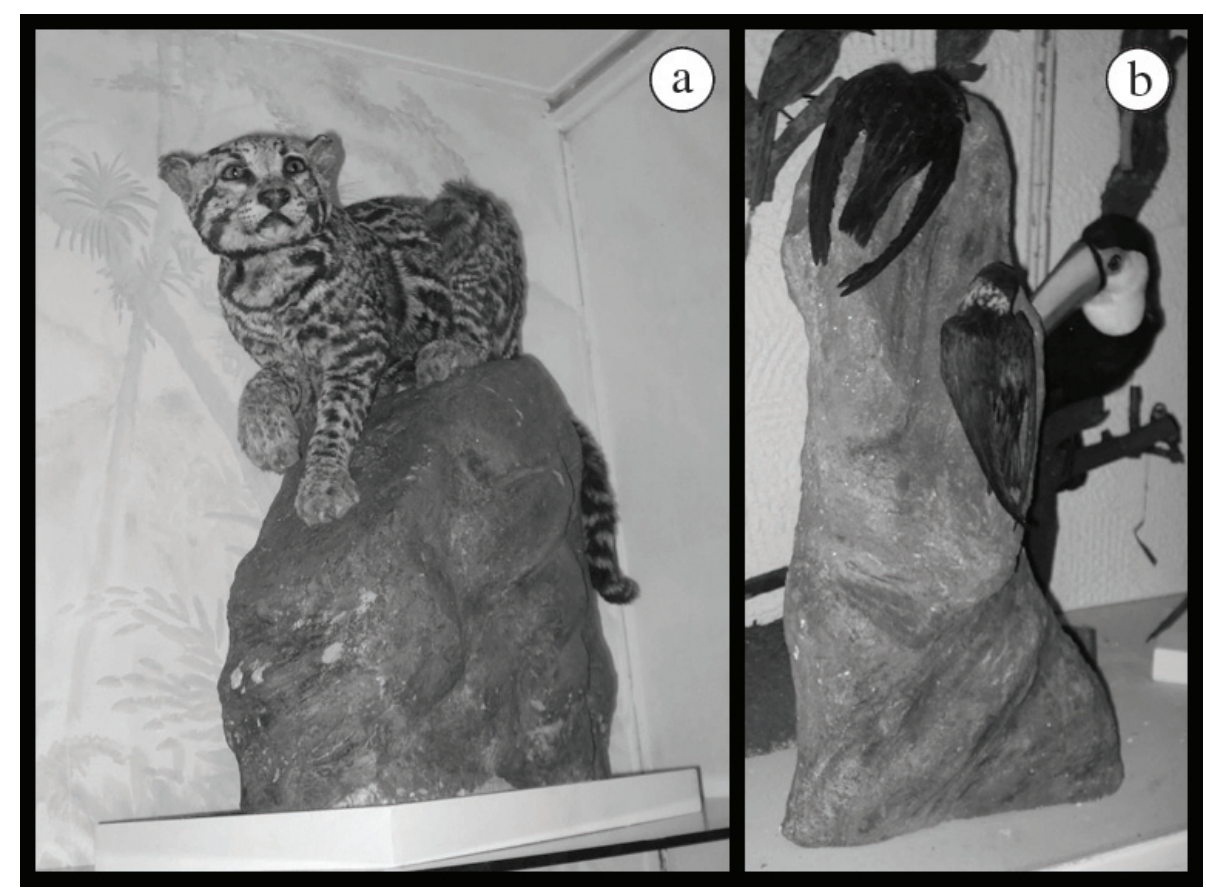

Figure 3. a - Leopardus wiedii, without number; b - Streptoprocne zonaris MN 27739, preparation technique and style of bases reporting to the collector and technician C. Mielke in the 1950s.

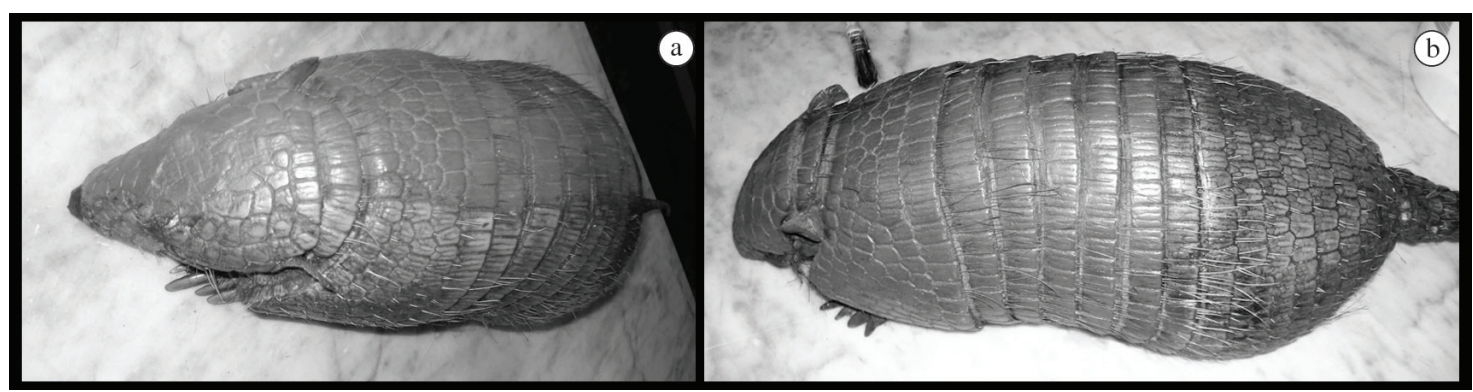

Figure 4. Euphractus sexcintus MN 54773, the specimen was painted masking the original color and details, a and b show the paint removal process.

exhibition of vertebrates of the Museu Nacional/UFRJ, 138 dry-preserved specimens were selected and were treated (Table 1).

This work reflects our experience with the application of methods available in the literature in a large collection of old specimens that has been maintained under minimal environmental control for decades, but which had been subject to mechanical stress and incorrect restoration methods in recent years. The mammal specimens cleaned and/or restored belong to the orders Primates, Carnivora, Artiodactyla, Perissodactyla, Didelphimorphia, Chiroptera and Rodentia. Among birds, specimens of orders Tinamiformes, Struthioniformes, Anseriformes, Galliformes, Sphenisciformes, Ardeiformes, Piciformes and Passeriformes were restored.

The first step was to create a database to document all stages of work, including the evaluation of each specimen, description of activities and the final result, all with photographic documentation.

In a few cases simple cleaning action, including dust removal with compressed air jet, was sufficient. In most cases, more specific actions were necessary for data recovery and cleaning, restoring, and removing products used in past interventions. In each phase of work, curators, researchers and technical staff worked as an integrated team discussing and evaluating interventions to be performed, and their results. In particular, we seek to preserve possible sources of genetic data and avoided the use of potentially harmful substances to skin, hair and feathers, as well as to genetic material. To remove dirt we used, whenever possible, coconut soap and alcohol, in place of other products recommended in the literature, such as trichloroethylene, bleach and acetone, which allow faster work, but may cause damage to protein and DNA. 


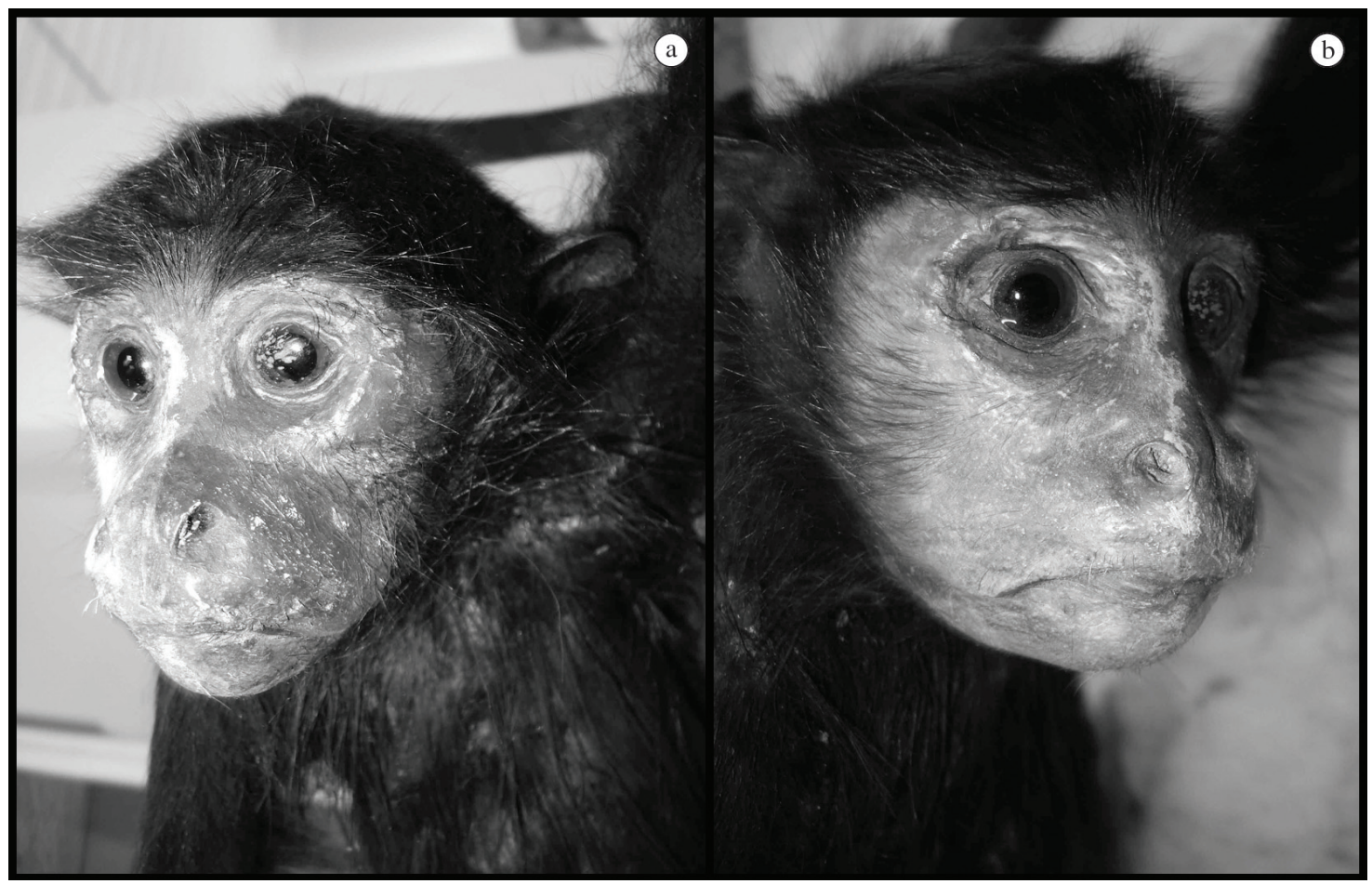

Figure 5. Ateles paniscus without number, the face of the specimen was painted several times in different periods. a - the thickness of the paint masks the original features; $b$ - the same specimen after the removal of paint.

Table 1. Description of specimens treated for the three exhibition rooms of the National Museum.

\begin{tabular}{llc}
\hline Skin & Aves & 56 \\
& Mammalia & 45 \\
Skeleton & Aves & 8 \\
& Mammalia & 29 \\
Total & & 138 \\
\hline
\end{tabular}

Such products in general have been used only in particular cases, as for the bird Casmerodius albus (MN 44662) to recover the natural white of its feathers.

In many cases, due to the various displacements of the specimens, it was necessary to reconstruct the anatomical parts that are most exposed to impact. Some parts, such as nails, fingers or teeth, had been lost. These were reconstructed with gypsum or epoxy resin paste. Other parts were broken, such as feet, legs, tails and ears. Feet, legs and tail were repositioned with new metal supports when necessary, and sew or glued with vinyl glue. Ears were reconstructed as proposed by Lotti and Barbagli (2008). For almost all specimens it was necessary to reestablish the natural color patterns of nails and noses and in some cases completely remove the paint applied throughout the body, as in the case of the specimens belonging to the family Dasypodidae, which had been colored without due care in a previous intervention.

To preserve the color of hair, skin and the genetic material of the specimens exposed, specific filters were applied to the fluorescent lamps in the cabinets designed to house the specimens, to limit the effect of ultraviolet ray emission.

The experience team in restoration activities at the Museu Nacional in 2011 allowed our staff to evaluate minimum standards of operating procedures for restoring biological collections of vertebrates. This procedure required that for each proposed technique and material, the following items should be considered: the historical and scientific value of the specimen, reversibility of the procedure, aesthetic effects, possible negative effects on future genetic and morphological analyzes, long-term effects and financial costs. Only after the evaluation off all items it can be decided if the technique and/or material is appropriate to perform the specific intervention.

\section{Acknowledgments}

We thanks to the rectory of UFRJ (SR-2) for the financial resources that allowed the restoring's activities of vertebrate's collection in the year 2011, and Miguel M. Fialho of Instituto Nacional de Controle de Qualidade em Saúde - INCQS/Fiocruz for the development of the database used in this project.

\section{References}

BARBAGLI, F., 2008. Preparazione, conservazione e restauro dei reperti naturalistici. In BARBAGLI, F. and MALERBA, G. (Orgs.). Preparazione, conservazione e restauro dei reperti naturalistici: 
metodologie ed esperienze. Verona: Associazione Nazionale Musei Scientifici. p. 7-9. Museologia scientifica: Memorie.

BORGO, E. and DORIA, G., 2008. Recupero di collezioni museali dopo um evento alluvionale. In BARBAGLI, F. and MALERBA, G. (Orgs.). Preparazione, conservazione e restauro dei reperti naturalistici: metodologie ed esperienze. Verona: Associazione Nazionale Musei Scientifici. p. 103-106. Museologia Scientifica: Memorie.

BRANDI, C., 1977. Teoria da restauração. Torino: Einaudi. 80 p.

Brasil. Ministério da Saúde. Secretaria de Ciência, Tecnologia e Insumos Estratégicos, 2006. Diretrizes gerais para o trabalho em contenção com agentes biológicos. 2. ed. Brasília: Editora MS. 52 p. Série A. Normas e Manuais Técnicos.

BRUNSTETTER, RT., 1988. Removing rust stains from bones. Curator, vol. 31, no. 2, p. 106-107. http://dx.doi. org/10.1111/j.2151-6952.1988.tb00680.x.

CATO, P. and WILLIAMS, S., 1993. Guidelines for developing policies for the management and care of natural history collections. Collection Forum, vol. 9, no. 2, p. 84-107.

CATO, P., DICUS, DH. and VON ENDT, D., 2001. Priorities for natural history collections conservation research: results of a survey of the spnhc membership. Collection Forum, vol. 15, no. $1-2$, p. $1-25$.

CLEVEDON BROWN, J. and STODDARD, DM., 1977. Killing mammals and general post-mortem methods. Mammal Review, vol. 7 , no. 2 , p. 64-144.

COETZEE, CG., 1985. The influence of preservatives on coat colour of small mammals. Acta Zoologica Fennica, vol. 170, p. 67-68.

COOPER, A. and POINAR, HN., 2000. Ancient DNA: do it right or not at all. Science, vol. 289, no. 5482, p. 1139. http://dx.doi. org/10.1126/science.289.5482.1139b. PMid:10970224

COUSIN, R. and DUBOSC, D., 1991. Le guide du moulage des poissons, reptiles et amphibiens. Dijon: OCIM. 36 p.

DAUXOIS, T., PEYRARD, M. and BISHOP, AR., 1993. Entropydriven DNA denaturation. Physical Review E: Statistical Physics, Plasmas, Fluids, and Related Interdisciplinary Topics, vol. 47, no. 1, p. R44-R47. http://dx.doi.org/10.1103/PhysRevE.47.R44. PMid:9960075

DE WET, E., ROBERTSON, P. and PLUG, I., 1990. Some techniques for cleaning and degreasing bones and a method for evaluating the long term effects of these techniques. In HERHOLDT, EM. (Ed.). Natural history collections: their management and value. Pretoria: Transvaal Museum. p. 37-47.

FLORIAN, ME., 1986. Ideas on how to better preserve collections of natural history: we now need to do something. Collection forum, vol. 2, no. 2, p. 6-7.

FRANÇA, JS. and CALLISTO, M., 2007. Coleção de macroinvertebrados bentônicos: ferramenta para o conhecimento da biodiversidade em ecossistemas aquáticos brasileiros. Neotropical Biology and Conservation, vol. 2, no. 1, p. 3-10.

GRAHAM, F. and SPAFFORD, S., 2001. Fire recovery at the Royal Saskatchewan Museum: part ii-post-disaster clean-up and soot removal. Collection Forum, vol. 15, no. 1-2, p. 45-56.

GUIMARÃES, L. and BECK, I., 2007. Conservação \& restauração de documentos em suporte de papel. In GRANATO, M., SANTOS, CP. and ROCHA, CRA. (Orgs.). Conservação de Acervos. Rio de Janeiro: MAST. p. 45-60. MAST Colloquia. vol. 9.
GÜTHS, S. and RODRIGUES DE CARVALHO, C., 2007. Conservação preventiva: ambientes próprios para coleções. In GRANATO, M., SANTOS, CP. and ROCHA, CRA. (Orgs.). Conservação de Acervos. Rio de Janeiro: MAST. p. 25-44. MAST Colloquia. vol. 9.

HAWKS, C., MCCANN, M., MAKOS, K., GOLDBERG, L., HINKAMP, D., ERTEL JUNIOR, D., SILENCE, P. and ROSSOL, M. (Eds.), 2010. Health and safety for museum professionals. New York: Society for the Preservation of Natural History Collections. $650 \mathrm{p}$.

HERHOLDT, EM., 1990. Vertebrate collections management: a personal perspective with special reference to Southern Africa. In: HERHOLDT, EM. (Ed.). Natural history collections: their management and value. Pretoria: Transvaal Museum. p. 1-11.

HOFREITER, M., SERRE, D., POINAR, HN., KUCH, M. and PÄÄBO, S., 2001. Ancient DNA. Nature Reviews. Genetics, vol. 2, no. 5, p. 353-359. http://dx.doi.org/10.1038/35072071. PMid:11331901

HORIE, CV., 1986. Who is a curator? International Journal of Museum Management and Curatorship, vol. 5, no. 3, p. 267-272. http://dx.doi.org/10.1080/09647778609515029.

HÖSS, M., JARUGA, P., ZASTAWNY, TH., DIZDAROGLU, M. and PÄÄBO, S., 1996. DNA damage and DNA sequence retrieval from ancient tissues. Nucleic Acids Research, vol. 24, no. 7, p. 1304-1307. http://dx.doi.org/10.1093/nar/24.7.1304. PMid:8614634

JANNETT JUNIOR, FJ. and DAVIES, JG., 1989. An inexpensive apparatus for degreasing skulls. Curator, vol. 32, no. 2, p. 88-90. http://dx.doi.org/10.1111/j.2151-6952.1989.tb00712.x.

KRISHTALKA, L. and HUMPHREY, PS., 2000. Can natural history museums capture the future? BioScience, vol. 50, no. 7, p. 611-617.

LANGE CANHOS, D., COLOMBO, A., MARINO, A., SOUZA, S., UMINO, CY., CRUZ, B. and ALBANO, APS., 2004. Trabalhos desenvolvidos no SinBiota Sistema de Informação Ambiental do Programa Biota/Fapesp pelo Centro de Referência em Informação Ambiental - CRIA. Available from: $<\mathrm{http}: / /$ sinbiota1.biota.org. br/info/sinbiota_mar04-set04.pdf >. Access in: 15 Sept. 2010.

LAPA, R., 2006. Riscos em laboratório: prevenção e controle. Rio de Janeiro: Cadernos de estudos avançados. p. 25-43.

LOTTI, S. and BARBAGLI, F., 2008. Il restauro dei trofei di caccia di Vittorio Emanuele II Allá Villa medicea della Petraia (FI). In BARBAGLI, F. and MALERBA, G. (Orgs.). Preparazione, conservazione e restauro dei reperti naturalistici: metodologie ed esperienze. Verona: Associazione Nazionale Musei Scientifici. p. 121-123. Museologia Scientifica: Memorie.

MARMUR, J., ANDERSON, WF., MATTHEWS, L., BERNS, K., GAJEWSKA, E., LANE, D. and DOTY, P., 1961. The effects of ultraviolet light on the biological and physical chemical properties of deoxyribonucleic acids. Journal of Cellular and Comparative Physiology, vol. 58, no. 3, p. 33-55. http://dx.doi.org/10.1002/ jcp.1030580406. PMid:14470098

MARCHETTI, S., 1984. L'arte della tassidermia. Florença: Olimpia.

MICHALSKI, S., 1994. A systematic approach to preservation: description and integration with other museum activities. In Preventive conservation: Practice, theory and research. Preprints of the contributions to the Ottawa Congress, 1994. Ottawa. London: International Institute for the Conservation of Historic and Artistic Works. p. 8 . 
MUGNAI, R. and AGNELLI, P., 2008. Riordino della collezione osteológica conservata nel Salone degli Scheletri Del Museo di Storia Naturale dell'Universitá di Firenze. In BARBAGLI, F. and MALERBA, G. (Orgs.). Preparazione, conservazione e restauro dei reperti naturalistici: metodologie ed esperienze. Verona: Associazione Nazionale Musei Scientifici. p. 131-132. Museologia scientifica: Memorie.

NATIONAL PARK SERVICE, 2005. The Museum Handbook Part I: Museum Collections. Washington: National Park Service. Appendix T: Curatorial Care of Biological Collections. Available from: $<$ http://www.nps.gov/museum/publications/MHI/AppendixT. pdf $>$. Access in: 25 Nov. 2011.

PILETTE, R. and HARRIS, C., 1989. It takes two to tango: A conservator's view of curator/conservator relations. Rare Books and Manuscripts Librarianship, vol. 4, no. 2, p. 103-111.

RAGIONIERI, R., 1961. Imbalsamazione degli uccelli. Firenze: Olimpia. 178 p.

Resource Group Integrator - RGI, 2000. Il contenimento del danno biologico nei musei, archivi e biblioteche. Genova: Tipolitografia Ata. 30 p.

ROSE, C., HAWKS, C. and GENOWAYS, H. (Eds.), 1995. Storage of natural history collections: a preventive conservation approach. Washington: Society for the Preservation. 448 p. vol. 1.
ROSE, CL. and TORRES, AR. (Eds.)., 1992. Storage of Natural History Collections: Ideas and Practical Solutions. Washington: Society for the Preservation of Natural History Collections. 346 p.

SAFRA, 2007. O Museu Nacional. São Paulo: Banco Safra. 359 p.

SCROCCHI, G. and KRETZSCHMAR, S., 1996. Guía de métodos de captura y preparación de anfibios y reptiles para estudios cientificos y manejo de colecciones herpetológicas. Tucuman: Fundación Miguel Lillo. 35 p. Serie Miscelánea.

SIMMONS, JE. and MUNHOZ-SABA, Y., 2005. Conservación preventiva y causas del deterioro de lãs colecciones. In SIMMONS, JE. and MUÑOZ-SABA, Y. (Eds.). Cuidado Manejo y Conservación de Colecciones Biológicas. Bogotá: Universidad Nacional de Colômbia. p. 54-71.

VAN VEEN, O. (Ed.), 1981. Bird mountin (The Jonas technique). Denver: Jonas Brothers I.N.C. 80 p. vol. I.

WARTELL, RM. and BENIGHT, AS., 1985. Thermal denaturation of DNA molecules: A comparison of theory with experiment. Physics Reports, vol. 126, no. 2, p. 67-107. http://dx.doi.org/10.1016/03701573(85)90060-2.

WILLIAMS, SL. and WALSH, EA., 1989. Developing chemical pest control strategies for museums. Curator, p. 34-69. 